\title{
Correlation Between Learning Outcomes Modeling Problem Solving Learning with Learning Outcomes of Preparation of Lesson Plant Prospective Biology Teachers
}

\author{
R. P. Puspitawati ${ }^{1}$, A. Basri ${ }^{2}$ \\ \{riniepratiwi@unesa.ac.id ${ }^{1}$ \} \\ Universitas Negeri Surabaya, Surabaya, Indonesia ${ }^{1,2}$
}

\begin{abstract}
Research has been conducted to measure the correlation between learning outcomes of lectures that apply problem solving modeling with learning outcomes for the preparation of lesson plants for Biology teacher candidates UNESA. This research is a quasi experiment with the method of "one shoot case study", which is applied to lectures on Plant Anatomy in three classes. Indicators of learning outcomes in the modeling process are innovative ideas and reflections generated by students when participating in modeling. Indicators of learning outcomes for the preparation of lesson plants in the form of quality aspects of the selection of materials and design of learning management and evaluation development. Data in the form of scores were analyzed by Pearson test. The analysis showed that there was a significant correlation, with a coefficient of $0.663 ; 0.829$ and 0.921 for three different classes. These results indicate that modeling lecturers when managing lectures is effective in teaching the preparation of a leson plant for prospective Biology teachers.
\end{abstract}

Keywords: Modeling, Problem solving, Lesson Plan

\section{Introduction}

Lectures can be a modeling of how to manage learning to achieve certain goals. It is necessary to plan a stage that facilitates students to evaluate and reflect on the lecture process that is followed, especially to evaluate and appreciate the lecture process that exercises problem solving skills. The lecture activities are repeated in each different topic, thus providing sufficient experience. Repeated experiences provide opportunities for students to gain retention of knowledge and experience, so they will be easily implemented [1].

Modeling learning management for prospective teachers is important. Through modeling can be taught teaching skills to prospective teachers well. The analysis results of the study by Sweitzer and Ronald show that effective teacher preparation procedures include systematic observation of learning practices, micro-teaching, and feedback (1983). The practice pattern is applied to the provision of prospective teachers of Biology Education Unesa study programs (2016).

Modeling allows the emergence of appreciation from students. Through appreciation, students examine, assess and compare what is learned in a learning model, so that it can bring up innovative ideas related to the process, known as appreciative inquiry. Appreciative inquiry 
is applied to complex social problems, which are related to building social conditions in managing learning [2].

Modeling is always trained in specific material contexts [3][4], and is very dependent on the specific domain of knowledge and its implementation strategy [5][6] . Other research results state that problem solving skills can be acquired and mastered if they are modeled with specific material content [3][7][8]. Modeling presents stages that facilitate students to evaluate and reflect on the lecture process that is followed, especially to evaluate and appreciate the steps of problem solving that have been done. The lecture activities are repeated in each different topic, thus providing a provision of experience. Repeated experiences provide opportunities for students to gain retention of knowledge and experience, so they will be easily implemented [1].

This research implements learning with specific strategies for prospective teachers, so that at the same time can learn about how to train problem solving for students. Specific strategies developed are related to the stages of problem solving learning to equip the skills to evaluate and appreciate the steps to solving problems. The expected stages of learning management are realized based on two main views, namely problem solving (problem solving) and positive problem solving views.

Positive problem solving views emphasize cognitive activity to identify success and strength, identify the factors that enable success, predict achievement, innovate to do the best work. This view forms the basis of Appreciative Inquiry (AI), which facilitates the emergence of ideas through skill appreciation activities [9][10], and is very relevant in the context of social problems complex [2]. According to Yew and Schmidt, this is different from problem solving learning which is more marked by repetition of concepts than the emergence of new concepts (2008).

Attempts to combine problem solving and positive problem solving approaches have been carried out for continuous improvement in the industrial sector, and bring up an approach called Appreciative Problem Solving [2]. Appreciative Problem Solving is an approach to finding the best things by analyzing the main problems to understand a system, and creating innovations to make improvements. This approach can be applied to assess the resolution of technical problems, and simultaneously analyze the social conditions of the system [2]. The application of this approach to the learning process, which is essentially a social system, allows students to appreciate the learning process that is followed. Students can find the advantages of the learning process, to finally be able to bring up innovative ideas.

In this study, management of learning was carried out which emphasized the appreciation of problem-based lectures, and related the ability of prospective teachers to develop problem solving learning plans. The ability to appreciate lectures is characterized by a number of indicators, namely (1) novel specimens or anatomical studies compared to specimens and studies in lectures; (2) reflection (evaluating the implementation of the process); (3) explain the stages of the problem solving process; (4) Identify the superiority of the stages of the problem solving process. The design of learning management produced by students in the subjects of Innovative Learning 2 (PI 2) includes, (1) planning teacher activities facilitates students to identify facts that have the potential to cause problems; (2) planning facilitates the formulation of problems by students; (3) planning student activities designing problem solving in groups; (4) planning facilitates the formulation of work plans to solve problems by providing formats. In detail the indicators are presented in Table 1. 


\section{Research purposes}

Explicitly the purpose of this study is to test whether there is a correlation between the ability of students to appreciate the learning process in botanical courses that implement problem solving strategies, with the quality of lesson plans in solving problems prepared by prospective teachers when attending the two innovative learning courses (PI2).

\section{Methodology of Research}

This study followed Pre-Experimental Designs with the design of "one shot case study" by Fraenkel and Wallen (2012), Creswell (2014), and Tuckman and Harper (2012). This research was conducted on 96 students of the 2015/2016 Biology Unesa Education study program. Students are divided into three groups (A, B, and U) according to class with the number of students in each class is 36,43 and 17 students. This research was conducted in even semester 2018/2019 for 9 weeks. Lectures are held from February to June 2018 at the Biology Department of the Faculty of Mathematics and Natural Sciences, UNESA. The implementation of the two cycles in this lecture is supported by lecture tools in the form of teaching materials, guidance on student activities, lecture units, valid assessment sheets.

Correlation statistical analysis was conducted to see whether there was a correlation between learning outcomes of the Learning Management Plan (Lesson Plant) in PI 2 courses with the results of learning innovative ideas and reflections on the course of Plant Anatomy. Correlation test was carried out by Pearson test, because the distribution of normal and homogeneous blood. The formulation of hypotheses to be tested through the Pearson test is as follows.

Ho: There is no correlation between the results of learning innovative ideas and reflection with the learning outcomes of compiling lesson plans.

Ha: There is a correlation between the results of learning innovative ideas and the learning outcomes of preparing lesson plans

In testing the hypothesis using a significance level $\alpha=0.05$ (two-tailed)

Ho rejection category based on p-value as follows.

If $\mathrm{p}$-value $<\dot{\alpha}$, then Ho is rejected

If $\mathrm{p}$-value is $\geq \dot{\alpha}$, then Ho cannot be rejected

\section{Results}

Pearson correlation test was conducted to see the correlation between the value of appreciation in the course of Plant Anatomy with the value of the learning design produced by college students in the course of Innovative Learning II. Learning outcomes were obtained through an assessment of the achievement of a number of indicators set. Indicators of appreciation in Plant Anatomy course and lesson plan in Innovative Learning II courses were presented in Table 1. 
Table 1. Related and Correlated Indicators between appreciation skills in Plant Anatomy and Lesson plan.

\begin{tabular}{ll}
\hline \multicolumn{1}{c}{ Aspects } & \multicolumn{1}{c}{ Indicators } \\
Appreciation skill in Plant Anatomy Idea (the idea of study Anatomy Plant) \\
courses
\end{tabular}

A summary of correlated values was presented in Table 2. Data analysis performed was correlation test. Pearson for data that has been done was normal distribution and homogenous. A summary of correlated values analysis in Table 3.

Table 2. A Summary of Correlated Values.

\begin{tabular}{llcc}
\hline Class & Aspect of data & $\begin{array}{l}\text { Skills of appreciation in } \\
\text { Plant Anatomy }\end{array}$ & $\begin{array}{l}\text { Lesson plan of } \\
\text { Innovative Learning II }\end{array}$ \\
\hline $\begin{array}{l}\text { Biology education } \\
\text { A }\end{array}$ & $\begin{array}{l}\text { Number of college } \\
\text { students }\end{array}$ & 31 & 31 \\
& Mean & 64,67 & 60,48 \\
Biology education & Standard deviation & 9,58 & 17,46 \\
B & Number of college & 40 & 40 \\
& students & & 75,37 \\
Biology education & Mean & 65,31 & 5,09 \\
$\mathrm{U}$ & Standard deviation & 6,90 & 16
\end{tabular}




\begin{tabular}{llcc}
\hline Class & Aspect of data & $\begin{array}{l}\text { Skills of appreciation in } \\
\text { Plant Anatomy }\end{array}$ & $\begin{array}{l}\text { Lesson plan of } \\
\text { Innovative Learning II }\end{array}$ \\
\hline Mean & 58,2 & 65,87 \\
& Standard deviation & 5,29 & 4,84 \\
\hline
\end{tabular}

Table 3. A Summary Result of Correlation Test Between Correlated Values.

\begin{tabular}{|c|c|c|c|c|c|c|}
\hline Class & Data Courses & & $\begin{array}{l}\text { P-value } \\
\text { (sig) }\end{array}$ & $\alpha$ & Summary & $\begin{array}{l}\text { Correlation of } \\
\text { coefficient }\end{array}$ \\
\hline \multirow[t]{2}{*}{$\begin{array}{l}\text { Biology } \\
\text { education A }\end{array}$} & $\begin{array}{l}\text { Innovative } \\
\text { reflection }\end{array}$ & and & 0,000 & 0,05 & Ho rejected & 0,921 \\
\hline & $\begin{array}{l}\text { Material planning } \\
\text { learning step }\end{array}$ & and & & & & \\
\hline \multirow[t]{2}{*}{$\begin{array}{l}\text { Biology } \\
\text { education B }\end{array}$} & $\begin{array}{l}\text { Innovative ideas } \\
\text { reflection }\end{array}$ & and & 0,001 & 0,05 & Ho rejected & 0,829 \\
\hline & $\begin{array}{l}\text { Material planning } \\
\text { learning step }\end{array}$ & and & & & & \\
\hline \multirow[t]{2}{*}{$\begin{array}{l}\text { Biology } \\
\text { education } U\end{array}$} & $\begin{array}{l}\text { Innovative ideas } \\
\text { reflection }\end{array}$ & & 0,000 & 0,05 & Ho rejected & 0,663 \\
\hline & $\begin{array}{l}\text { Material planning } \\
\text { learning step }\end{array}$ & and & & & & \\
\hline
\end{tabular}

$\alpha=0,05$ If $\mathrm{P}$-value $<\alpha$, then Ho rejected If $\mathrm{P}$-value $\geq \alpha$, then Ho accepted

The result of analysis in all class show Ho rejected, that mean there is significant correlation between appreciation skills with lesson plan creating skills. in plant anatomy course. Correlation coefficient obtained were positive are 0.663 for the Biology education A class, 0.829 for the Biology education B and 0.921 for the Biology education A.

The results of the analysis can give an idea that appreciation skills in study of plant anatomy over all has positive correlation with lesson plan creating skills to practice problem solving skills in Innovative Learning 2 course (PI 2).

Learning outcomes in designing learning management from three classes are known to be not significantly different. The percentage of students completing in each class varied between $65.63-87.81 \%$, and the overall average reached $76.15 \%$. The selection aspect of the project in the learning design that allows problems to arise in the implementation of the basic concept reaches an average proportion of 0.55 . The biggest proportion is 0.96 in the indicator choosing the project based learning method and the base learning problem.

Difficulties in selecting topics and phenomena to raise problems appear from the low achievement of proportions, which is 0.57 . This shows that students are able to present real phenomena related to the concepts being taught, but still need to be improved. According to Mayer, selection and presentation of phenomena relevant to problem-based learning and project-based which emphasizes authentic problems (2008).

The choice approach model or the right model to teach problem solving skills is achieved with the indicator 0.96 . The steps for managing learning planned to teach the skills to solve achievement problems have a fairly high level and exceed the minimum criteria for 
completeness. The data can be an indicator that students are able to design learning management to practice problem solving skills.

Indicators of assessments in the Lesson Plant to assess problem solving activities are designed by students to assess the project, and achieved with a proportion of 0.92 . The proportion of the complete rubric on the assessment reaches 0.75 . Overall, it can be said that the indicators for implementing Lesson Plant can be achieved beyond the minimum criteria.

The Lesson Plant is related to innovative ideas that are trained through Plant Anatomy courses, and significantly positively correlated. The constructed correlation connects innovative idea indicators in plant anatomy with several indicators in designing lesson plans.

This correlation is very possible because $90.91 \%$ of students in the field test understand the lectures that have been experienced in Plant Anatomy as work processes for problem solving, discussion and presentation. Among these students a total of $39.39 \%$ of students were able to reflect in detail on the stages of the lecture, which consisted of problem formulation, designing problem solving, collecting data, concluding and presenting results. This is considered as a new lecture strategy by $87.87 \%$ of students.

The data can be interpreted that between the ability to reflect and appreciate can influence ideas and possibly actions to be taken after gaining experience through modeling. Referring to Bandura's modeling theory which says that there can be changes in cognitive, affective and behavior as a result of the process of observing and interacting with other behaviors and their explanations [11]. Students can learn through observation and explanation from others. Students must pay attention to the model that will be used as a model in the learning process. In order for procedural knowledge to be possessed it can be remembered, students must repeat and produce it again [11]. This can be seen from the SIPM learning experience that is repeated in lectures on Plant Anatomy, and is reproduced when students take part in the course of Innovative Learning 2 (PI 2).

This correlation is reinforced by the results of Moreno (2010) study, stating that positive learning outcomes can be obtained from a modeling. This is reinforced by the fact the results of student responses related to the topic of the problem proposed as a reflection of innovative ideas that are able to be reflected show that $11 \%$ of students study the relation of anatomical structure to environmental conditions, so the topic of the problem proposed is related to anatomical structure with environmental conditions (17\%) . The biggest percentage is $89 \%$ of students feel that they learn the concept of plant anatomical structure, so they assume the problems raised are related to the concept of plant anatomical structure $(82 \%)$.

The acquisition of the data reinforces the results that lectures are applied effectively to give a good appreciation so that they can bring up innovative ideas for managing learning. The inspiring experience is the lecture process carried out in plant anatomy courses, while appreciation allows students to produce a product in the Innovative Learning 2 course (PI 2), which occurs through modeling in the courses taken earlier.

\section{Conclusion}

There is a correlation between the ability to appreciate the learning process of plant anatomy as a learning model that is managed by problem solving strategies with problem solving Lesson Plant that were successfully compiled by prospective teachers in the PI 2 lecture. These results indicate that the process of appreciation planned and measured structurally through measurable indicators can provide positive learning outcomes in preparing lesson plans in the next course. 


\section{References}

[1] Destalia, Lendy, Suratno, \& Apriliya, S.: Peningkatan hasil belajar dan keterampilan pemecahan masalah melalui penerapan pembelajaran berbasis masalah $(\mathrm{pbm})$ dengan metode eksperimen pada materi pencemaran lingkungan. Jurnal Pancara, 3(4), pp. 213-224 (2014)

[2] Hansen, D.: Appreciative problem solving. binder paper submissions word appreciative inquiry conference may 2012 (2012)

[3] Gilles, C. N. R., Kratochwill, T. R., Felt, J. N., Schienebeck, C. J., \& Vaccarello, C. A.: Problem solving consultation: Applications in evidence-based prevention and intervention (2011)

[4] Hadijah, H.: Peningkatan kemampuan pemecahan masalah matematis siswa kelas vii melalui penerapan model pembelajaran creative problem solving (CPS) berbasis kontekstual. Jurnal Penelitian pendidikan dan Pengajaran,.1(4), pp. 303-308 (2017)

[5] Funke, J., Fischer, A., Greiff, S.: The process of solving complex problems. The Journal of Problem Solving, 4(1), pp. 19-42 (2012)

[6] Sitti, S., Sopeerak, S., \& Sompong, N.: Development of instructional model based on connectivism learning theory to enhance problem-solving skill in ICT for daily life of higher education students. Procedia - Social and Behavioral Sciences, 103, pp. 315-322 (2013)

[7] Green, L., \& Ruggiero, D.: Problem solving through digital game design: a quantitative content analysis. Computers in Human Behavior, 73, pp. 28-37 (2017)

[8] Funke,J., Frensch. P.A.: Complex prolem solving: The europan perspective-10 years after, in d,h Jonassen (ed,), learning to solve complex scientific problem, New Yoork : Lawrence Arlbarum (2007) [9] Henderson, M., Lee,S., Whitaker, G., Altman, L.: Positive problem-solving: How appreciative inquiry works. Strategies and Solutions for Local Government Managers, pp. 43(3) (2011)

[10]Tosati, S., Lawthong, N., Suwanmonkha, S.: Development of an appreciative inquiry and assessment processes for students' self-knowing and self-development. Procedia-Social and Behavioral Sciences, 19, pp. 753-758 (2015)

[11] Moreno, R. (2010). Educational psychology. New York: John Wiley \& Sons, Inc (2010) 